\title{
PRIORITIES FOR IMPROVING SOFTWARE EFFICIENCY IN THE DIGITAL ECONOMY
}

Mirzayev Qulmamat Jonuzoqovich,

Dsc in Economics, Samarkand Institute of Economics and Service

Azizkulov Baxtiyor Xushvaktovich,

$\mathrm{PhD}$ in Economics, Samarkand Institute of Economics and Service

\section{ABSTRACT}

The article describes the indicators for creating an electronic database to improve the efficiency of software in the digital economy through the implementation of practical and innovative research on the transition of the economy to the digital direction, the assessment of their status.

Keywords

digital economy, national concept, smart education, intellectual potential, digital knowledge, software, education integration, competitive human resources, technological development

Article Received: 18 October 2020, Revised: 3 November 2020, Accepted: 24 December 2020

To ensure the socio-economic development of our country, the transition to a new, improved stage of education in line with the principles of the digital economy and sustainable development is one of the most important tasks today. In turn, today's modern developments in the world economy prove that this urgent task can be solved in direct connection with the transition to a new economic model and "smart education". In particular, President Sh. Highly appreciating the role and importance of the digital economy in building a new Uzbekistan, Mirzayev said in his address to the parliament that we need to develop a national concept of digital economy, which provides for the modernization of all sectors of the economy on the basis of digital technologies. On this basis, we need to implement the "Digital Uzbekistan2030" program. ${ }^{1}$ "Of course, we know very well that building a digital economy requires the necessary infrastructure, a lot of money and manpower. But no matter how difficult it is, if we don't start today, when will we start? It will be too late tomorrow. "Active transition to the economy

1 https://uza.uz/oz/posts/o-zbekiston-respublikasiprezidenti-shavkat-mirziyoyevning-o-22-12-2018 will be one of our top priorities for the next five years," he said. ${ }^{2}$

At the present time, the development of the country does not depend only on the available natural resources or population. According to the World Bank, $66 \%$ of the total wealth of our Kurrai land - \$ 365 trillion - falls on human capital, mainly on the scientific level of the individual. In the United States, that figure is 77 percent to $\$ 95$ trillion. That is why the head of our state said in his Address this year, "The greatest wealth is intelligence and knowledge, the greatest heritage is a good upbringing, the greatest poverty is ignorance!" mentioned separately. It is the wing of intelligence and progress. The pinnacle of modern science is in high technology, in the digital world. The fourth industrial revolution marked the beginning of a new form of development - the "digital economy". To date, it is estimated that there are $\$ 2$ trillion in the 20 most developed digital economies in the world. Let's take for example UK, the world leader in the development of the digital economy, it has already reached $12 \%$ of the gross domestic product. The digital economy implies the digitization of technological

2 https://uza.uz/oz/posts/o-zbekiston-respublikasiprezidenti-shavkat-mirziyoyevning-o-30-09-2020 
and business processes, production, logistics and sales of finished products.

The formation of the digital economy is characterized by the active use of information and communication technologies to implement various interactions between all participants in economic processes. The digital economy provides a variety of information, educational, scientific and entertainment content in a faster, more quality and more accessible way. The digital economy is a new business process, a new market economy. ${ }^{3}$ The digital economy is an idea it was announced by the World Bank in its 2016 World Development Report 2016: Digital Dividends. The World Bank is showing signs of digitalization in the country, such as open data, e-government systems, digital giants such as Yandex and Kaspersky, online ordering services, and a 10-day reduction in property rights registration. To date, more than 7,000 health care, preschools and schools have been connected to high-speed Internet, while another 12,000 institutions have been connected to high-speed Internet in the next 2 years under this program, and another 12 in the next 2 years under this program. thousands of institutions are expected to have high-speed Internet access. $^{4}$

Digitization is the creation of a new product in digital form. For example, an animated dynamic training course or an interactive system of document interpretation is digitization. It is not possible to transfer a digitally-based product to physical means without a serious loss of its quality, so digitization, unlike digitalization, allows businesses to grow significantly faster and gain new competitive advantages. What will be the digital future, what social, economic and other challenges will we face along the way; our future represents digital slavery (perhaps a matrix); the triumph of humanity, spirituality and intelligence

3 Tursunov F.U. (2020) Digital Economy and Globalization: the Importance of Digital Entrepreneurship Development.// Journal of Innovations in Economy, 2020, vol.6, issue 3, pp.17-20

4 https://uza.uz/oz/posts/o-zbekiston-respublikasiprezidenti-shavkat-mirziyoyevning-o-30-09-2020 over various problems and difficulties; our actions will depend on expediency, intensity, and coherence.

There is no common understanding of the digital economy phenomenon in the world today, however, there are many definitions. The official definition of the state is as follows: digital economy - the use of the results of their analysis and large-scale processing of various types of production, technology, equipment, storage and sale of goods and services in comparison with traditional forms of management. big data in digital form, which allows to significantly increase the efficiency of delivery, is the main activity of the farm. According to various estimates, the digital economy means huge changes for us in more than $50 \%$ of different industries. ${ }^{5}$ This can be explained by the fact that it radically changes business models by increasing efficiency by optimizing information technologies and platforms and eliminating intermediaries.

To prevent the global problems mentioned above, humanity needs a modern education system that conforms to the digital economy model and the principles of sustainable development. The solution to this problem is directly related to the transition to a new economic model and "smart education". It is based on:

- first of all, although the state reforms aimed at building a new Uzbekistan are aimed at ensuring the material, spiritual and social wellbeing of every member of our society in building a democratic state, human labor, high intellectual the potential cannot be achieved without the participation of specialists with modern knowledge based on digital technologies;

- secondly, the training of qualified personnel and competitive specialists with such digital knowledge and modern information technologies is achieved only through continuous stages of education;

5 Lapidus L.V. Cifrovaya ekonomika: upravleniye elektronnim biznesom I elektronnoy kommerciey. - M.: INFRA-M, 2019 
- thirdly, in the age of technological progress, in order to ensure that our country does not lag behind the development of the world, but can compete with them on an equal footing, as well as to further increase its position and power in the world economy. development of targeted educational programs for the continuous acquisition of digital knowledge and modern information technologies in higher education and beyond;

- fourth, the formation of a modern education system aimed at the transition to "smart education" is a key factor in improving the effectiveness of continuous acquisition of digital knowledge and modern information technology;

- fifth, the entry into the higher education system of young people who have deeply mastered the modern knowledge and innovations of "smart education", have their own independent views, ideas and goals, are thirsty for knowledge and demanding creates a source of efficient performance of the engine with unparalleled power.

\section{Methodology}

As a result of our research, changes in the software and use of the digital economy have been studied, and scientific conclusions and recommendations have been developed to improve the efficiency of software in the future through the development of the digital economy. The methodological basis of the research was formed as a result of the study of theoretical and practical data, legislation and other legal documents, literary sources and publications. The study was based on the connections between theory and practice, but also used methods such as analysis, comparison, and synthesis.

\section{Results}

The analysis shows that the digitization of economic processes is becoming a comprehensive trend that covers not only the direct information and communication network, but also all areas of economic activity in the country. The revolution of the digital economy in e-commerce, digital agriculture, "smart" grid systems, unmanned vehicles, and healthcare is being felt strongly. In this context, individual companies, regions, countries and their associations are actively involved in the formation and implementation of strategic decisions in the digital economy, striving to ensure the long-term competitive advantages that are emerging in the markets of new technologies, goods and services. At the same time, it is necessary to address a number of issues related to the assessment of the consequences of the implementation of the benefits of the digital economy in individual sectors and regions of the country. "The digital economy is a virtual environment that complements reality."

Therefore, the Resolution of the President of the Republic of Uzbekistan dated November 22, 2018 states $^{6}$ : "It is important to create conditions for the rapid development of the digital economy, further improve the system of public administration, expand access to it, use modern infrastructure." implementation of the infrastructure for the development of the digital economy. Recently, a new interpretation has emerged: the digital economy is in addition to the analog economy, which is able to stimulate the development of real sectors. The most important stage of the impending struggle is not economic and technological competition, but the formation of a new paradigm of civilization that unites humanity, allowing it to define the key stages in presenting and building a clear and attractive image of the future. Countries with the highest levels of leadership treatment have already embarked on research in this area, but the pinnacle of such research at the moment is the idea of Impact Investing. Digital transformation has reached different levels, and the difference between them has the same meaning as the difference between the two terms- "digitalization" and "digitization". Digitization is the transfer of

6 O’zbekiston Respublikasi Prezidentining “Raqamli iqtisodiyotni rivojlantirish maqsadida raqamli infratuzilmani yanada modernizaciya qilish choratadbirlari to'g'risida"gi Qarori// Newspaper "Xalq so'zi”, Nov.22, 2018 
information from physical to digital means. Examples of digitalization include e-books, video courses, digital photocopying, and more. There is no change in the structure of information: it is only in electronic form. Digitalization is often used to improve an existing business model and optimize business processes.

The Organization for Economic Cooperation and Development (OECD) reports are also of particular interest in terms of assessing the impact of the digital economy on public administration and community development. According to a 2016 survey conducted by the OECD in 32 member countries and 6 other partner countries, they have a strategy, plan or program for the development of the digital economy. In September 2017, the Australian government announced that it had begun developing a digital economy strategy. The table shows the goals of the digital economy development conducted by the OECD based on the analysis of existing strategies and surveys.

7 Gulyamov S.S., Ayupov R.H., Abdullayev O.M., Baltabayeva G.R. Raqamli iqtisodiyotda blokcheyn tehnologiyalari, T:TMI, "Iqtisodiyot-Moliya"nashriyoti, 2019, 447 p. 
Table 1 The priority of digital economy development goals in OECD countries

\begin{tabular}{|c|c|c|c|}
\hline \multirow[t]{2}{*}{ Aims of the developing digital economy } & \multicolumn{2}{|c|}{ Priority } & \multirow{2}{*}{$\begin{array}{l}\text { The number of } \\
\text { countries } \\
\text { involved in the } \\
\text { strategy }\end{array}$} \\
\hline & 2017 & $\begin{array}{c}\text { 2020-2022, } \\
\text { change in } \\
\text { grade }\end{array}$ & \\
\hline Improving e-government services & 1 & 0 & 21 \\
\hline Development of telecommunication infrastructure & 2 & -3 & 22 \\
\hline Promoting ICT skills and competencies & 3 & 0 & 16 \\
\hline Strengthening security & 4 & +2 & 18 \\
\hline Expanding data access & 5 & +1 & 6 \\
\hline $\begin{array}{l}\text { Encouraging the adaptation of ICT to business, } \\
\text { including small and medium-sized businesses }\end{array}$ & 6 & -1 & 3 \\
\hline $\begin{array}{l}\text { Encouraging ICT adaptation in specific sectors, such } \\
\text { as health and education }\end{array}$ & 7 & +1 & 3 \\
\hline Strengthening the protection of personal data & 8 & 0 & 5 \\
\hline Enhancing digital identification & 9 & 0 & 2 \\
\hline $\begin{array}{l}\text { Development of the ICT sector, including } \\
\text { international markets }\end{array}$ & 10 & 0 & 2 \\
\hline Promoting e-commerce & 11 & -1 & 5 \\
\hline $\begin{array}{l}\text { Addressing global challenges, including the Internet, } \\
\text { government, climate change, and more. }\end{array}$ & 12 & +1 & 1 \\
\hline Strengthening consumer production & 13 & -1 & 0 \\
\hline $\begin{array}{l}\text { Expanding Internet access, including for the elderly } \\
\text { and people with disabilities }\end{array}$ & 14 & +1 & 4 \\
\hline Maintaining Internet openness & 15 & 0 & 4 \\
\hline \multicolumn{4}{|c|}{ Additional goals of national strategies } \\
\hline $\begin{array}{l}\text { Encouraging science, innovation and } \\
\text { entrepreneurship }\end{array}$ & & & 16 \\
\hline $\begin{array}{l}\text { Providing access to the Internet, services and } \\
\text { information }\end{array}$ & & & 12 \\
\hline Developing digital content and culture & & & 10 \\
\hline Expanding the use of digital technologies & & & 10 \\
\hline $\begin{array}{l}\text { Developing a normative approach to the digital } \\
\text { environment }\end{array}$ & & & 3 \\
\hline
\end{tabular}

The table data outlines a total of 20 goals for the digital economy, including 15 goals proposed by www.psychologyandeducation.net the OECD and 5 more goals included in the national digital economy strategies of individual 
countries. Currently, the most important goals are "improving e-government services" and "developing telecommunications infrastructure." These two goals are more common in national strategies.

The analysed content of the Digital Economy Development Goals is characterized by the fact that the survey mainly processed data on developed and to some extent developing countries (Brazil, Mexico, Russia, etc.). The information provided does not reflect the views of many developing and least developed countries. To this end, issues related to addressing the negative effects of digitalization, including unemployment, technological and economic backwardness, and increasing dependence on a small number of transnational (large) corporations, have not been addressed. At the same time, in order to invest effectively in the national digital economy and receive dividends, it is necessary to develop not only ICT infrastructure in terms of global networks, but also a favourable business environment "analogue add-ons", significant human capital and good governance. The latter is the foundation of economic growth, so defining them as a set of measures and priorities, required investments and risk assessment to maximize efficiency represents a complex and pressing issue for professionals and government officials responsible for shaping the digital segment of the country's economy.

In defence of new technologies, it can be said that, unlike the positive effects, the negative effects are always more pronounced and, as a rule, appear earlier. The introduction of the Internet of Things will lead to an increase in medical services and quality of life, but this effect will come only after attempts to manipulate society. On the other hand, a compensation mechanism will be developed over time for each negative manifestation of technology.

In the context of complete transparency of information, firstly, it is impossible to hide anything, and secondly, more importantly, it can be considered that it is impossible to deceive, because it is easier to verify the truth. The generation of modern schoolchildren and students intuitively understands that maintaining prestige is difficult and therefore becoming more valuable. In practice, your "generalized internet profile" becomes your fixed capital, an asset that is formed from the day you first enter the network, and as with everything in the digital world, this asset has a dimension: friends, subscribers, and likes. soni. The World Bank estimates that a $10 \%$ increase in the number of high-speed Internet users could increase annual GDP growth from $4 \%$ to $1.4 \%$. The fact that the share of countries in GDP is growing at about $20 \%$ per year is a recognition of the importance of the role of e-economy, which in developed countries averages 7\%. In 2010, the Boston Consulting Group estimated the digitization volume at $\$ 2.3$ trillion for a group of 20 countries, or $4.1 \%$ of GDP. If the growth rate is maintained, in 10-15 years the share of such an economy in world GDP will reach 30-40\%. In developing countries, $1 \%$ of the total workforce is in the ICT sector, which directly creates a relatively small number of jobs, but the number of people employed in other sectors where high technology serves their development is growing 1 job in the ICT sector against $4.9^{8}$ In the digital economy, new opportunities for entrepreneurship and self-employment are also expanding rapidly. The World Bank Group's report needs to better understand the nature of the interactions with other factors called "analogue supplements." These include the following components:

- a base that creates a dynamic business environment and allows businesses and households to improve the living environment, reduce costs, make full use of digital technologies for innovation and competition, and create a highly dynamic business environment;

- skills that enable businesses and government employees to take advantage of IT opportunities;

- Institutions that promote the use of information technology (government agencies and private companies).

8 http://www.review.ru/\%/\#hot/pop/home/ 
New social models of interaction based on the integration of modern information platforms lead to the implementation of new economic technologies. Here, organizational management consists of a set of completely new methods and tools of data processing integrated into lacquered technology platforms which assist to create, transmit, store and display information products (data, ideas, knowledge) in a targeted manner, as well as ensure the maximum reduction of transaction costs for the interaction of economic agents.

\section{Discussions and conclusions}

The above cases will serve to solve the following problems: Improving the efficiency of software in the digital economy through the development of smart education, aimed at the transition to a new economic model and smart education:

- active provision of the teaching staff and teachers who have effectively mastered digital knowledge and modern information technologies, which play a central role in improving the effectiveness of software in the digital economy on the basis of the development of smart education;

- as a result of increasing the effectiveness of digital economy software based on the development of smart education, higher education institutions will increase the level and effectiveness of students' mastery of digital knowledge and modern information technologies;

- as a result of increasing the efficiency of digital economy software based on the development of smart education, the integration of general secondary education and higher education will intensify, and ultimately, digital technologies will be effective in building a new Uzbekistan based on the model of economic development of digital Uzbekistan. intellectual youth capable of implementation and management - systematic training of competitive personnel;

- increasing the share of the digital economy in GDP by $30 \%$ in the near future by increasing the efficiency of digital economy software based on the development of smart education.

To solve these problems, it is necessary to conduct practical and innovative research on the issues of creating a transition of the economy to digital directions as an integral part of the national concept of the digital economy. At the same time, it is expedient to fully involve highly qualified managers and teachers working in higher education institutions and research institutes. Therefore, the creation of an electronic database by increasing the efficiency of software in the digital economy serves to assess and forecast their current state. As a result:

1. Economic relations based on market principles will be improved in order to increase the efficiency of digital economy software based on the development of smart education.

2. The content of teaching the issues of data collection, storage, processing will be formed by increasing the efficiency of the software of the digital economy, and the curriculum, program will be developed and implemented in the educational process.

3. By increasing the efficiency of the software of the digital economy in educational institutions will be created a textbook "Developing the skills of listeners and teaching innovation" (teaching creativity and critical thinking).

4. The creation of a business environment (private sponsorship and innovation agency) that sponsors innovators and innovations in higher education institutions and the share of profits from innovation will be targeted.

5. In order to organize training courses for integrated areas of education (educational institutions) through the development of smart education, a didactic complex, interactive teaching technologies will be developed.

6. With the implementation of the developed methodological system, the indicators of mastering of students studying in higher education institutions, students of management courses organized in advanced training and retraining institutions are diagnosed and the effectiveness of training is assessed. 


\section{References}

[1] Decree of the President of the Republic of Uzbekistan dated February 19, 2018 "On measures to further improve the field of information technology and communications"

[2] Petition of the President of the Republic of Uzbekistan to Oliy Majlis. Retrieved from https://uza.uz/oz/posts/o-zbekiston-

respublikasi-prezidenti-shavkatmirziyoyevning-o-22-12-2018

[3] Petition of the President of the Republic of Uzbekistan to Oliy Majlis. Retrieved from https://uza.uz/oz/posts/o-zbekistonrespublikasi-prezidenti-shavkatmirziyoyevning-o-30-09-2020

[4] Tursunov F.U. (2020) Digital Economy and Globalization: the Importance of Digital Entrepreneurship Development.// Journal of Innovations in Economy, 2020, vol.6, issue 3, pp. 17-20

[5] Dobrinin, A.P. Cifrovaya ekonomika razlichniye puti k effektivnomu primeneniyu tehnologiy (BIM, PLM, CAD, IoT, Smart City, Big Data i drugiye). M:2016

[6] Gulyamov S.S. Ayupov R.H., Abdullayev O.M., Baltabayeva G.R. (2019) Raqamli iqtisodiyotda blokcheyn tehnologiyalari, T: TMI, "Iqtisodiyot-Moliya" nashriyoti, 447 pp.

[7] Lapidus L.V. Cifrovaya ekonomika ${ }^{\wedge}$ upravleniye elektronnim biznesom I elektronnoy kommerciyey. M: Infra-M,

[8] Mirzaev, K.J. (2010). Methodological issue of improving the efficiency of agricultural services. Monograph. Tashkent: "EconomyFinance" Publishing House

[9] Nasimov I.Kh., Mirzaev Q.J. (2015) Transport cluster and its essential features // Conference on "Regional innovation systems in Agriculture," Kangwon National University, Samarkand Agricultural Institute, Samarkand. 